\title{
Democracy and Corruption
}

\section{Citation}

Philip B. Heymann, Democracy and Corruption, 20 Fordham Int'I L.J. 323 (1996).

\section{Published Version}

http://ir.lawnet.fordham.edu/ilj/vol20/iss2/1/

\section{Permanent link}

http://nrs.harvard.edu/urn-3:HUL.InstRepos:12967838

\section{Terms of Use}

This article was downloaded from Harvard University's DASH repository, and is made available under the terms and conditions applicable to Other Posted Material, as set forth at http:// nrs.harvard.edu/urn-3:HUL.InstRepos:dash.current.terms-of-use\#LAA

\section{Share Your Story}

The Harvard community has made this article openly available.

Please share how this access benefits you. Submit a story.

\section{Accessibility}




\title{
Fordham International Law Journal
}

\section{Democracy and Corruption}

\author{
Philip B. Heymann*
}

Copyright (C) 1996 by the authors. Fordham International Law Journal is produced by The Berkeley Electronic Press (bepress). http://ir.lawnet.fordham.edu/ilj 


\title{
Democracy and Corruption
}

\author{
Philip B. Heymann
}

\begin{abstract}
I was asked to speak about corruption and democracy. I have a long history of concern about that relationship. The subject of corruption and democracy is best broken into three separate areas. First, there are questions of corruption that have no special relationship to democracy at all. Still, they present very important practical and moral issues which I will identify. Second, I will examine the particular relationships of corruption and democracy. Third, I will review the democratic means for fighting the problem of corruption.
\end{abstract}




\title{
ADDRESS
}

\section{DEMOCRACY AND CORRUPTION*}

\author{
Philip B. Heymann**
}

\section{Introduction}

I was asked to speak about corruption and democracy. I have a long history of concern about that relationship. In the United States, I helped establish the Watergate Special Prosecution Force that investigated and prosecuted the wrong-doings of the Nixon Administration. ${ }^{1}$ I was our chief prosecutor during the Carter Administration and responsible at that time for our ABSCAM investigation ${ }^{2}$ and prosecutions where, in the name of a fictional Middle-Eastern Sheik, we offered money in exchange for legislative services to a number of Congressmen and Senators. ${ }^{3}$ We received too many affirmative responses. ${ }^{4}$ I was most recently the first Deputy Attorney General under President Bill Clinton where I had to address, among other matters, the investigation of our most powerful Congressman, ${ }^{5}$ the Chairman of the House of Representatives Committee that deals with taxation, for various matters as to which he has now pled guilty. ${ }^{6} \mathrm{Be}-$ tween those occasions, I have worked in Guatemala and South Africa and, to a lesser extent, Russia-all places where the subject of corruption and democracy has at times been very rele-

* This Address was originally given at the Milenio Foundation conference on corruption in Latin America and Europe held in Bogota, Colombia on July 2-4, 1996.

** Philip B. Heymann is James Barr Ames Professor of Law, Harvard University Law School.

1. Charles R. Babcock, Heymann of Harvard, Watergate Ex-Aide, Picked for Justice Job, Wash. Post, Mar. 29, 1978, at A9.

2. John T. NoONAN, JR., Bribes 606-07 (1984). The U.S. Government used a fictitious business, Abdul Enterprises, as a cover for a sting operation. Id. at 605. ABSCAM is a contraction of Abdul and scam. Id.

3. Id. at $604-19$.

4. See id. (describing success of ABSCAM); United States v. Myers, 635 F.2d 945, 947-48 (2d Cir. 1980) (summarizing ABSCAM operation).

5. See Toni Locy, Rostenkowski Fraud Plea Brings 17-Month Sentence; Former Ways and Means Chief Fined $\$ 100,000$, WASH. Post, Apr. 10, 1996, at Al (describing sentencing of Representative Dan Rostenkowski).

6. Id. On April 9, 1996, Rostenkowski pleaded guilty to two counts of mail fraud and was sentenced to 17 months in prison and fined US\$100,000. Id. 
vant. Finally, I have met with experts and delivered talks in Mexico and Argentina over relatively extended periods, again on the subject of corruption and democracy.

The subject of corruption and democracy is best broken into three separate areas. First, there are questions of corruption that have no special relationship to democracy at all. Still, they present very important practical and moral issues which I will identify. Second, I will examine the particular relationships of corruption and democracy. Third, I will review the democratic means for fighting the problem of corruption.

\section{CORRUPTION WITHOUT SPECIAL REFERENCE TO DEMOCRACY}

Perhaps like many people, I tend to think of the problems of corruption in terms of the way in which they may undermine democratic institutions. The great scholars of corruption address its effects more broadly than this. I had in mind two of my own countrymen, Judge John Noonan ${ }^{7}$ who wrote an extended history of bribery, ${ }^{8}$ tracing it to periods, places, and institutions that were not at all democratic, and Professor Robert Klitgaard, ${ }^{9}$ who has written about the economic and developmental effects of corruption, ${ }^{10}$ again often in places that are not democratic:

These two scholars differ in their approach to corruption. Both recognize that it has a somewhat unusual double meaning. The first definition in many dictionaries is purely moral, referring to any conduct or individual that is depraved, perverted, or debased morally. The second definition is often more closely associated with dishonesty or, even more narrowly, with the improper use of a position of trust for personal benefit. Klitgaard is most concerned with the practical consequences of betrayal of the trust that has been placed in an individual in giving him a particular position in business or government. ${ }^{11}$ Noonan em-

7. Reagan's Circuit Nominees Confirmed in 1985, Legal Times, Jan. 6, 1986, at 5. Judge Noonan sits on the Ninth Circuit Court of Appeals. Id.

8. NOONAN, supra note 2.

9. Robert KuitgaArd, Controllinc Corruption (1988) [hereinafter Control LING CoRruption]. Robert Klitgaard is professor of economics at the University of Natal, South Africa. Robert Klitgaard, What Can Be Done? Fighting Corruption, UNESCO Courier, June 1996, at 34.

10. Controlling Corruption, supra note 9.

11. Id. at 11-12, 190. 
phasizes the far broader, moral meaning of being somehow depraved. ${ }^{12}$ Nevertheless, both focus on the giving and receipt of private benefits in exchange for favored treatment by a government official who is supposed to be deciding the matter without regard to his own private interests. ${ }^{13}$

Corruption, as secretly receiving private benefits to affect a decision that is supposed to be made in the interests of others and uninfluenced by private gain, is not solely a problem of governments. In this sense, a buying agent for a corporation may also be corrupt by demanding kickbacks to influence his purchasing decisions. Corruption is certainly not a problem solely of democracies. Some of the worst corruption has taken place under highly undemocratic governments including the Communist governments of the Soviet Union and the People's Republic of China and the authoritarian governments of regimes such as those in Zaire and Nigeria.

In terms of Judge Noonan's interest in morality, all of these settings share certain morally relevant characteristics. When an individual who has been placed in a position of trust on the understanding that he will act on behalf of someone else's interest and in accordance with certain understood criteria instead receives or demands personal benefits with the understanding that these will influence his decision, there is a betrayal of trust, there is deception and fraud, and there is a misuse of power. The victim of the betrayal of trust is whoever gave the individual the right to act on his behalf. The victims of the misuse of power include those who are denied the opportunity to deal with an organization on honest terms. Both groups are victims of the fraud. These concepts are so basic that it is unsurprising to find that every nation forbids bribery as a core form of immorality. ${ }^{14}$

From the perspective of Professor Robert Klitgaard, the purposes of an organization that placed trust in a dishonest agent are defeated by that dishonesty. ${ }^{15}$ If it is a company trying to buy the best material for its manufacturing process, it is likely to get something else. If it is a government trying to prevent environmental degradation, it will be unable to accomplish this. Cor-

12. NoONAN, supra note 2 , at 702-03. 48.

13. Id. at 685, 704-05; ConTrolling CoRruption, supra note 9 , at $\mathrm{x}-\mathrm{xi}, 10-11,46-$

14. NoONAN, supra note 2 , at 702-03.

15. Controlling Corruption, supra note 9 , at 47. 
ruption is not inconsistent with rapid growth as major nations in Asia, Latin America, and Europe have demonstrated. ${ }^{16}$ Businesses can come to understand a corrupt regime. But corruption is inconsistent with carrying out purposes of an administration that may be in conflict with the wishes of wealthy players in the private sector. In the long run, it is inconsistent with innovation by businesses spurred on by competition. Illicit payments become a tempting substitute for lower prices or product innovation.

The short of the matter is that even the most primitive and simple of enterprises cannot run without trust among its members. Cooperation requires trust, and truly efficient cooperation requires a willingness to commit oneself to wholehearted pursuit of the objectives of the enterprise. That trust cannot survive the payment of private benefits to a person who has agreed to take part in the cooperative enterprise and has been given the power of others on the understanding that those benefits will be used solely for their purposes in order to induce him to divert the powers granted to pursue the quite different objectives of someone outside the enterprise. Bribery of its members is, therefore, a practice that every organization forbids and states enforce this prohibition when dealing with legitimate enterprises where cooperation is to be encouraged.

A word of caution is in order before leaving this most general area of cooperation. In real life, it is impossible to wholly separate private motivations from the use of authority entrusted for specific, non-personal purposes. Not every bit of loyalty to a family member or a clan, not every hope for a future employment or a valued friendship, may be forced out of the minds of people entrusted with authority for other specific purposes. So lines have to be drawn, and different lines are drawn in different societies. To recite the set of conflict of interest rules in the United States would take a long time. That the precise location of the line, however, is a subject of dispute or even arbitrary does not weaken the general notion that we must forbid payments intended to breach the trust on which cooperative undertakings depend.

16. See id. at 30-36 (discussing corruption as aid to economic growth). 


\section{DEMOCRACY AND CORRUPTION}

Latin Americans know better than most the use that leaders of military coups have made of the issue of corruption. It is probably the single charge most frequently set forth as a justification for a military take over. A century ago, Nietzsche said that corruption is simply the sign of the autumn of a nation. ${ }^{17}$

I remember being in Guatemala City early in the administration of President Vinicios Cerezo, ${ }^{18}$ at a time when he was already being charged with various improprieties. ${ }^{19}$ Colonels on several bases decided to launch a coup. ${ }^{20}$ They were not stopped by any significant number of people taking to the streets but by the Minister of Defense, whose centrality to the infant democracy on that occasion made clear just how fragile the democracy was. A few days later, President Cerezo attempted to show popular support for democracy and his administration by organizing a public parade. Few people appeared; the procession consisted almost entirely of school children brought in from the countryside. Suspicions of corruption had weakened the public demand for democracy to the point where it depended solely on the loyalty and judgment about reactions of foreign governments of General Hector Gramajo, the Defense Minister. Similarly, many believe that support for democracy in Russia is today dangerously thin, in large part because of popular resentment of corruption in President Yeltsin's administration.

One critical relationship between corruption and democracy is thus that corruption can deeply undermine support for democracy in any fragile democracy. Corruption of an administration in the United States is very likely to lead to the election of the opposing party. The U.S. democracy, however, is an old and stable one where the basic institutions are not still questioned. Where democracy is younger and more fragile, corruption 1974).

17. Friedrich Nietzsche, The Gay Science, $\$ 23$, at 98 (Walter Kaufmann trans.,

18. Douglas Farah, Guatemalan President Dashes Backers' Hopes, WASH. Post, May 13, 1995, at A21. Vinicios Cerezo was President of Guatemala from 1986 until 1991. Id.

19. See, id. (describing Guatemalan discontent with Cerezo); Ken Anderson \& Jean-Marie Simon, Guatemala Democracy is an Army in Disguise, L.A. Times, May 29, 1988, at 2 (criticizing army dominance of Guatemala and ineffectiveness of Cerezo); Wider Army Unease Behind Failed Coup, LATIN AM. WKLY REP., May 26, 1988, at 3 (describing May 11, 1988 coup attempt).

20. Wider Army Unease Behind Failed Coup, supra note 19, at 3. 
seems a reason to abandon democracy completely in favor of some form of other government that, it is hoped, will be free of that vice.

In these contexts, where democracy is not firmly rooted, the question of corruption becomes whom does a democratic government in fact serve? President Abraham Lincoln of the United States spoke 134 years ago in the Gettysburg Address about a government "of the people, by the people, and for the people" and asked whether it could long endure. ${ }^{21}$ We are asking whether any other kind of democratic government can endure. A corrupt, democratic government is likely to look like it is for the wealthy and the well-connected, not a government by and for the people. If the choice to much of the population appears to be one between elected figures serving the interests of narrow but wealthy constituencies or authoritarian governments serving much broader interests, democracy is very much at risk.

Democracy is also more vulnerable to charges of corruption than other forms of government for two reasons. First, the freedom of speech, press, and political challenge that comes with democracy allows opponents of a corrupt administration to make much of its corruption. A military government or the government of a totalitarian communist regime simply does not tolerate this. Second, democracies have the special problem of funding expensive political activities. If they are not to be funded from tax revenues, they must be funded by private individuals who will want something from the candidates they support. Campaign contributions are rarely disinterested. Candidates know from whom they come and why, and candidates remember that they will need them again. Their discharge of a trust afforded them by all of the people is inevitably affected by their personal interest in raising the funds necessary to be elected. This is a form of bribery, however reluctant we may be to use that term, and it undermines the support of elected governments in a way that has no application to other governments.

Finally, there is the question of whether it is harder or easier to attack corruption in a democracy. I think it should be easier. The people of every country hate corruption and feel cheated by

21. Abraham Lincoln, Address at Gettysburg, Pennsylvania (Nov. 19, 1863), in Abraham Lincoln, Speeches and Writings 1859-1865 536 (Library of America 1989). 
it. The more a government is responsive to its citizens' wishes, the more likely the agents of government will feel a counterbalance to the temptations of corruption. Moreover, the existence of a free press provides an important mediator for public opinion. It can discover and document instances of corruption and reveal them to sizable populations. That can be a powerful deterrent.

In describing these relationships of corruption and democracy, I have been too general in several ways. Some final distinctions may be useful. Corruption may take place at a high level or at low levels throughout a system. It may be widespread and systematic at whatever level it is operating, or it may be sporadic and occasional. Obviously the threat that corruption will create cynicism, suspicion, and eventually citizen distrust not only of an administration but of the very manner by which administrations are chosen, democratic elections, depends upon which of these areas of corruption is present. High-level corruption is far more dangerous to democracy than low-level corruption. If the highest levels are honest, citizens are more likely to seek a change in administration to demand honesty at lower levels. Systemic corruption is far more dangerous to democracy than occasional and sporadic corruption. It may change the entire outlook of a population, leaving the trustworthy feeling as if they have been foolish and encouraging children as well as adults to accept cheating as a way of life.

\section{WHAT CAN BE DONE IN A DEMOCRACY TO END CORRUPTION?}

I have spent weeks discussing problems of corruption in Argentina, and I have recently returned from conversations with Italian magistrates addressing corruption in Milan, Naples, Palermo, and Rome. I have spent years dealing with corruption in the United States. Every nation is unique in its particular forms of corruption and in the institutions and powers it has available for dealing with them. Every democratic nation is unique in the support that the fight against corruption enjoys from high government officials and from the public at large. Still, there is a logic to the problem of a democracy fighting corruption that is general wherever the corruption may be. I will try to describe 
that logic, apologizing in advance for the extent to which I will be emphasizing the techniques used in the United States.

Choosing the United States as an example is not simply a matter of convenience because that is my country. It is also useful because the United States has been relatively successful. I consider the level of corruption in the United States low for a country so vast and diverse and with such complicated governmental structures. A good way of making this point is to say that there are few if any places or types of governmental activities where one could safely offer money to an executive, legislative, or judicial official to influence his or her decision. The United States has brought about a high measure of compliance with a relatively limited commitment of law enforcement resources (about two hundred years of FBI agent time each year and perhaps about a hundred years of federal attorney time) and a pattern of internal inspectors general in any state or federal department affecting significant private interests.

\section{A. Four Ways of Reducing Corruption}

To understand the problem a democracy faces in controlling corruption, it is a useful exercise to imagine trying to create a setting for corruption so perfect that even a decently honest person would be tempted severely. Quite simply, we would want a situation with a large bribe, unlikely to be detected, and an atmosphere in which one was thought to be foolish, rather than honorable, in declining such opportunities.

To get the large bribe, we need high stakes for private interests and realizing those stakes must turn on a governmental decision by a single individual. If the decision is made by the concurrent decision of a number of people, the rewards will decrease and the risk will grow. For safety from detection, the decision must either be so discretionary, so lacking in standards, that the purchased choice will not look suspicious, or it must be hidden in the obscurity that characterizes some of the lowest level of governmental choices.

Even with these conditions met, most of us would feel a strong moral compulsion not to take a bribe. After all, as Judge Noonan points out in his book on bribes, every nation has for- 
bidden them ${ }^{22}$ and the prohibition is millennia old. ${ }^{23}$ To make the perfect setting for a bribe, we need a solvent of conscience. That would be an atmosphere in which everyone believed that loyalty was for fools, that everyone took what they could get, and that one deserved ridicule more than praise for turning down an opportunity to enrich one's self in an official capacity. In addition, conscience pangs may be reduced by a plausible argument that the particular type of payment would not really influence one's decision, that the decision did not really matter, or that accepting money on this occasion fell into an exception to the rules about bribes.

Our task, in fighting corruption, is to eliminate as many of these conditions as possible. Part of the difficulty is that they reinforce each other. It may not be possible to change the mores of an organization or of the government without reducing the opportunities for corrupt advantage. But it is politically difficult to take the hard steps necessary to reduce the opportunities for corruption so long as cynicism smothers social demands for honesty. The job of the corruption fighter is to deal with both of these conditions simultaneously by making visible the corruption that will outrage the citizenry in a democracy and, with the support of that public reaction, bringing cases that show that corruption is not safe.

Corruption, thus, can and should be addressed simultaneously in four different areas. The first two are major ways of attempting to deal with corruption, but each of them requires significant changes in what might otherwise be the preferred way of conducting the business of government. First, market conditions can be created to reduce the private stakes that turn on the decision of any single individual. Second, government operations can be changed to reduce the discretion exercised by officials. The third approach is to change public and organizational attitudes towards self-dealing when using government authorities. I am going to focus, however, on a fourth set of alternatives, the development of management and law enforcement strategies with the object of making corruption apparent despite the desire of the parties to keep it secret.

22. NoONAN, supra note 2, at 702-03.

23. See id. at $\mathbf{x x}$ (dividing history of bribery into epochs). 


\section{B. Strategies to Make Comuption Visible}

The central concept behind both management and law enforcement strategies is coming to understand the difficulties of engaging in corruption secretly in different settings. To engage in corruption, a government official and a private party must identify each other as potential corrupt partners, find a way of reaching an agreement, and then deliver what each has promised without being detected. Each of these steps can be extremely difficult, for in each there are vulnerabilities to detection.

Let me give you an example. How could a judge who wanted to be corrupt in adjudicating a civil case let a litigant know that he is willing to take a bribe without exposing himself to investigation and prosecution? If a judicial rule generally forbids meeting with a single party in the absence of the other, any private meeting will raise suspicions and is likely to be detected. Putting that impediment in the way of a secret transaction is an important management tactic as part of an overall strategy of making the secrecy necessary for corruption difficult and uncertain. Moreover, the litigants before the judge are likely to change regularly so there are too many for the judge to contact safely with a corrupt offer. It would be much safer to deal through particular lawyers, but they will have to let litigants know of their contacts with the judge and that, too, imposes risks. It may also be difficult for the judge to deliver. If he is regularly reversed by higher courts in cases involving a particular attorney who always seems to win, that may be noticed by opposing attorneys and lead to rumors that then come to the attention of law enforcement authorities.

In short, the processes that are necessary to market corruption have vulnerabilities attached to them. Exploiting those vulnerabilities, once identified, is the central concept of any law enforcement or management strategy to control corruption. Identifying these vulnerabilities to detection requires coming to understand, for different settings, what tradition or practicality is likely to dictate the mechanics of three things: finding corrupt partners, making payments, and delivering what is purchasedeach in an inconspicuous way. Corruption is likely to work in ways dictated by an organization's routines and local social conditions. 
The corrupt deal also depends upon the particular area of governmental activity. Beyond mere theft of government property, the methods of carrying out corruption and, thus, the vulnerability to detection is likely to differ in the cases of different forms of police corruption, sale of exemptions from regulation or tax collection, grease payments to speed a slow process, corrupt procurement, sale of access to inside information, legislation, and judicial decisions. Different strategies are necessary depending upon the different situations and ways in which corruption takes place because the strategies should depend upon how vulnerable to detection each type of corrupt business is in the tasks of finding corrupt partners, making payments, and delivering what is purchased.

\section{The Importance of the Tools of Management}

I have spoken of law enforcement and management strategies because we have learned that preventive management strategies are, in some settings, as important as law enforcement strategies. To deal with widespread or simply low level corruption, prosecution is likely to be too costly, clumsy, and sporadic an answer. Management controls are essential. Management strategies also have the advantage of allowing the chief to put into place systems that will make more visible unusual decisions, or unusual benefits, or the agreements that link them. I have already mentioned computer systems and requirements of approval by several officials. Periodic review of decisions, reporting requirements in terms of an employee's changing financial assets, and conflict of interest rules are all familiar examples. Management systems can also allow remedial action to be taken earlier and on a less certain basis than criminal prosecution.

There is a paradox about the notion of fighting corruption by management change in internal operating systems. A dishonest employee who is prepared to take a bribe in exchange for forgoing the obligations he has assumed will also be willing to ignore or circumvent record keeping, review, or other management requirements designed to make any corrupt action more visible. So the crucial characteristics of any management device designed to prevent corruption are that efforts to circumvent the device are more likely to be detected than would corruption without it and that compliance makes corruption either more 
visible or, like the U.S. prohibition of judges meeting with one party alone, more difficult to carry out.

\section{The Needed Political and Institutional Structures}

Finally, we have learned that a set of institutional and political structures of support are necessary to carry out either a law enforcement or a management strategy against corruption. Making use of law enforcement and management strategies based on analysis of the vulnerability to detection of corruption in different settings depends on four conditions being satisfied:

1. The necessary substantive laws defining illegal conduct and the necessary laws creating preventive measures, such as a rule requiring sealed bids or forbidding ex parte meetings with judges;

2. The needed management, auditing, and investigative powers to find out if the substantive laws are being complied with;

3. The necessary organizational structures to carry out the enforcement of the laws; and

4. Sufficient popular political support for attacking corruption to induce elected leaders at a high enough level to tackle it i.e., to carry out the previous steps:

a. General public outrage over corruption; and

b. Threat of media or legislative disclosure of whatever corruption is ignored or covered up.

These deserve special attention in any discussion of the relationship of corruption to democracy.

IV. CREATING THE NEEDED STRUCTURES FOR POLITICAL AND INSTITUTIONAL SUPPORT IN FIGHTING CORRUPTION

\section{A. Clarifying the Legal and Organizational Obligations to Avoid Self-Dealing}

The first step of carrying out a strategy for dealing with corruption in a particular area or in all areas is to define with some precision what is forbidden. As Judge Noonan notes, throughout history this has proved far more difficult than we sometimes 
recognize. ${ }^{24}$ The questions of definitions for criminal purposes that we have found most difficult in the United States are:

- In what situations should we prohibit or limit campaign contributions intended to win the favor of a particular official or, at least, gain preferred access to him or her?

- How do we deal with reciprocity where there is no articulated understanding or quid pro quo, particularly when there is a chain of reciprocity that involves more than two people?

- Is receiving some benefits in exchange for exercising discretion in a particular way permissible if the government loses nothing; for example, where it is buying a uniform good or service that sells for an established price from one seller rather than another?

- When is it all right to furnish advanced information and when is it wrong?

- Is it a conflict of interest for a government official to continue to decide matters of importance to company $\mathrm{X}$ when he or she anticipates seeking employment from the company but no negotiations have taken place?

All of these are very difficult questions.

In other countries, another problem of definition is fundamental, the line between a gift and a bribe. In some countries, for example Germany, it is improper to start an investigation unless investigators know what the official did in exchange for the money. In the United States, it is sufficient that an official knew that something was given in appreciation for an official act. Beyond that, the United States has specific ethical prohibitions for receiving gifts. ${ }^{25} \mathrm{I}$ attended a conference on corruption in Berlin during February of $1995 .{ }^{26}$ A number of the German speakers addressed the corrupting effect of gifts given for five or six years before a favor is even asked. They spoke of prices being thirty percent higher in public construction in Frankfurt and it being almost impossible for an honest competitor to compete when large presents are accepted without thought and reciprocity is considered absolutely natural.

The managerial rules must also be made explicit. How fully

24. See Noonan, supra note 2 , at $687-90,695-99$ (distinguishing types of reciprocal exchanges).

25. 18 U.S.C. $\$ 201$.

26. Korruption in Deutschland: Ursachen, Erscheinungsformen, Bekämpfungsstrategien (Berlin, Feb. 16-17, 1995). 
are decisions to be documented? How much of a record must be kept? What forms of review will there be? What are the internal rules for disqualification?

The point is simply that we all have a general idea of what conduct is so self-serving that it should be forbidden by criminal law or management provisions. But the extent of vagueness and disagreement within that general category itself poses a substantial impediment to fighting corruption. Clarifying the rules is a necessary first step.

\section{B. The Need for Investigative and Managerial Powers to Determine if the Rules are Being Followed}

It is well to begin with a reminder of a half dozen serious difficulties facing those fighting corruption whether by managerial or criminal processes. First, those who know about the corruption are likely to be participants or close friends of participants and unwilling to furnish information. Second, participants will not willingly create records that disclose the existence of corruption. Third, efforts to discover corrupt officials by having investigators pretend to be private parties willing to pay for a governmental decision are often regarded as politically motivated or immoral unless there is first significant evidence that corruption is ongoing in a particular area. Fourth, investigators often fear economic or other reprisals by the subjects of an investigation. Fifth, the complexity of the business and government setting in which corruption may take place is likely to pose grave difficulties for investigators who are unfamiliar with the activities they are reviewing. Finally, fighting corruption is made more difficult by the fact that often the merits of a decision are unclear so that it is almost impossible to identify highly unusual governmental actions. We should think about the needed law enforcement and managerial powers against this background.

Even this imposing list of difficulties may hide a deep-seated problem in investigating corruption. I know it is deeply troublesome in each of our countries. Broad public cynicism will undermine a healthy democracy. Thus, members of Congress in the United States complain bitterly about the attitude many in our public have towards them. I am sure it is much worse in some other countries. Preventing corruption, the only real cure for cynicism, requires, however, that police, prosecutors, and 
management be vigilant and indeed suspicious in watching for corruption. Because the temptation is always present, corruption will reappear if we do not watch for it.

Watching requires investigating by internal units or by police and prosecutors, and there is nothing that elected or career officials like less than public investigations of their activities. Investigations invade their privacy, damage their reputations, make it more difficult for them to continue in office, and damage public respect for their institutions. Thus, corruption investigations are the least popular form of law enforcement among officials, although often the most popular with the public at large.

I was confronted with this dilemma sharply in the ABSCAM investigations in the United States. There were rumors that members of Congress were willing to take money in exchange for legislative action. Such rumors themselves, especially if not responded to, breed public cynicism. In response, the FBI offered money to whomever was rumored to be willing to take it. A number of members of Congress took the FBI bribes. ${ }^{27}$ The resulting scandal was immensely resented by perfectly honorable members of our Congress, some of whom had been investigated and many of whom had not. ${ }^{28}$ Failing to follow-up on the rumors, however, would have bred distrust. The situation is typical of that confronting law enforcement officials after they have learned of suspicions or rumors of corruption and before they are quite sure of who is involved and who is not. In that intermediate stage, every effort to detect wrong-doing is likely to be interpreted as an unfair invasion of privacy, causing improper damage to an individual's and an institution's reputation. In the long run, however, the price of public trust in its elected and other officials is that law enforcement officials follow-up on rumors and investigate.

\section{The Needed Law Enforcement Powers}

The powers of law enforcement officers must be adequate to become aware of likely corruption, to turn suspicion into evidence, and to rebut the passionate denials of one of two parties to a corrupt exchange.

How do investigators become aware of a problem of corrup-

27. Noonan, supra note 2, at 607-10; Myers, 635 F.2d at 947-48.

28. NoONaN, supra note 2, at 616-19. 
tion in a particular area? In the United States, they will follow media reports and pursue rumors and suspicions of those who work in an area that, because of tradition or vulnerability to corruption, is likely to be corrupt, and they will invite complaints, anonymous or otherwise, by competitors, clients, or fellow employees. Investigators will also establish formal auditing procedures to review records that are required to be kept by particular government officials or by private individuals who may be paying a bribe. Beyond this, by making known the seriousness with which the United States takes corruption, the U.S. Government lets criminals of all sorts know that their cooperation in uprooting corruption is likely to reduce their sentences.

To transform a reasonable suspicion that there is corruption in a particular area into a criminal prosecution, investigators need the power to review official records of the actions of suspected officials to detect patterns of favoritism. They need to be able to subpoena private financial records in the hope of finding evidence of improper payments or receipts. It helps greatly if investigators may trade a reduced sentence or immunity from prosecution for testimony from someone who works in the area of suspected corruption but who has been caught giving a bribe or in another crime and is anxious to make a deal. In Italy, as in the United States, some investigators have learned that allowing bribers to declare themselves the victims of extortion will generate a great deal of evidence of bribe-taking. ${ }^{29}$ Finally, investigators may disguise themselves as corrupt individuals and offer to engage in corrupt transactions.

To deal with the problem of the lack of credibility as a witness of someone who has engaged in corrupt transactions himself and now stands to benefit by a reduced sentence, the U.S. Government relies extensively on the use of recording devices or microphones. Then the informant or undercover agent can be asked to discuss past, ongoing, or future corrupt activities with a suspect. The tape of the resulting conversation will more than offset the difference in credibility between a high level govern-

29. See, e.g., Selwyn Raab, New York Officials of Plumbing Union Charged in Bribery, N.Y. Times, Oct. 15, 1993, at 1 (stating that New York District Attorney's office does not indict bribers who are victims of extorsion); Brunella Giovara \& Nino Pietropinto, Torino, interrogato Romiti; All'uscita dalla procura: é andato tutto bene. I legali: ha fornito le spiegazioni richieste, LA STAMPA, June 16, 1995 (reporting that Fiat employees accused of bribery were later treated as victims of extortion). 
ment official and someone who has admitted to being a bribe giver.

\section{The Needed Management and Auditing Powers}

Managers need the power to do whatever is necessary to assess honesty in hiring. A lack of background checks has been blamed for the extent of police corruption in some of our cities such as Washington, D.C. 30 Managers need the power to test employees by providing false opportunities for corruption or by establishing systems to monitor what people with financial interests regularly select which officials to deal with. Unions often object to such tests, but these tests are essential. Managers who strongly suspect that corrupt activities are taking place need the power to transfer or reassign individuals without proof of their involvement in corruption. Much corruption may be prevented by regularly rotating individuals, thereby disrupting established relations with those paying graft.

In addition, managers need the power to transfer and reassign subordinates who are making no effort to deal with likely corruption in areas under their responsibility. In New Orleans, for example, where a number of officers were found to be engaged in drug dealing ${ }^{31}$ and recently one convicted of contracting for murder, ${ }^{32}$ the chief of police needed the power to impose some form of sanction on supervisors who did nothing to prevent this conduct. They also needed more punitive sanctions to fire or suspend officers. Non-vested pension rights can help a great deal.

Besides these powers over the individual employee, managers fighting corruption need the powers to shape an organization's processes so as to make an individual exercise of discretion less frequent and more transparent in cases where the decision is of substantial financial importance to private individuals or organizations. The manager can involve more than one person in making the decision and require review of the decision at higher levels. He or she may require bidding procedures. He or she may impose record-keeping requirements that may help by

30. Philip P. Pan, D.C., P.G. To Recruit 400 Officers; Hirings are Largest Since ' 89 '90 Expansion, WASH. POST, May 19, 1996, at B1.

31. Adam Nossiter, Police in New Orleans: Film Noir in Real Life, N.Y. Times, Dec. 19, 1994, at A14.

32. Former Police Officer Sentenced To Death, Times-Picayune, Nov. 7, 1996, at B3. 
identifying the irregular government decision or forcing the corrupt employee to an uncomfortable choice between revealing the irregular transaction or falsely accounting for it and risking discovery or failing to account altogether for it and risking discovery.

Often it is easier to identify a missing or false record than to find the underlying offense. Finally, the manager may need the authority to destroy trust in the market for corruption by having honest officials pose as corrupt and then report any overtures.

Armed with these powers, law enforcement and government managers largely can deter corruption if they have the advantage of the organizational structures necessary to use these powers to enforce the rules. So, let us turn to that.

\section{The Necessary Organizational Structures to Enforce the Rules}

The final capacity that both managers and law enforcement officers need is the power to create offices that are motivated, skilled, and independent to enforce the rules I have just described. Such structures are needed in at least four places. There must be effective inspection and auditing units within every organization. Some police investigative units must be specialized in public corruption. Prosecutors have to have sufficient credibility as well as skills in these cases. Additionally, courts must be available to try cases of corruption within a reasonable period of time and with adequate accuracy.

\section{Internal Inspection Units}

As a start, only such units may become highly specialized in the work and, thus, in the possibilities and vulnerabilities of corruption in the highly specific setting of a particular governmental function or location. Part of the problem is skills. Police are not normally trained in the accounting and auditing skills that are necessary for detecting corruption in complicated financial or business transactions. Part of the problem is experience. Internal investigators can and will become expert enough in the business of the agency to detect unusual patterns in records or visible behavior. A final part is concentration of effort. An internal agency may best put together a portfolio of preventive detection and remedial measures for a manager anxious to fight corruption. 
In addition, an internal inspection agency may be given the power to put in place or to recommend that there be put in place internal processes to create the information sources which are likely to reveal otherwise hidden corruption. These will often be management information or other record-keeping systems. Sometimes, there will be simply a network of human contacts. The latter is particularly important in police work.

What are the crucial conditions necessary for such agencies to play their role? Investigators need vigorous support for their mission at the highest level of the agency. The agency head may demonstrate that support by the vigor with which he or she pursues any signs of corruption. The agency head may be brought to want to demonstrate such support by being held responsible for corruption in the agency whether or not he was aware of it and by making sure that information about corruption in the agency is likely to be brought out by the press, independent auditors, or investigative committees. Such internal investigative units also need independence from the threat of later reprisals by those within or outside of the agencies whose activities are being systematically reviewed.

With all of these powers and support, the success of an internal anti-corruption agency depends importantly upon the internal culture of the parent organization. Where corruption is thought of as normal, employees feel they have nothing to lose by way of reputation or adequate pay, and everyone believes someone else will be corrupt if not they. It may take mammoth steps, far beyond the powers of an internal anti-corruption agency, to change that culture. The problems are doubly complicated when the parent organization is thought to be incompetent in many ways, for incompetence results in decisions that are often indistinguishable from one of the telltale signs of corrupt decisions, inexplicability.

\section{Specialized Police Units}

Specialized police units must supplement internal investigative units as one of the important checks on their vigor and integrity. Moreover, only a police unit may carry an investigation outside of an organization, examining the activities of the private parties involved in corruption. Furthermore, in the United 
States, often police are much better trained to turn information about corruption into a form that is usable in criminal trials.

Why do we need these specialized units? As we have seen, anti-corruption laws are difficult to interpret. Anti-corruption investigations are necessarily more intrusive and, therefore, more difficult and sensitive than investigations in which there is a victim to complain. A specialized police corruption unit is likely to develop an esprit de corps that will generate the energy necessary to sustain interest over time. Furthermore, because corruption investigations are likely to be long, officers who are not specialized and who are dealing with other matters will find the urgency of violent crime displacing the long-term demands of fighting corruption.

The members of these units particularly need protection against the retaliation of powerful political figures. They need specialized training. They should learn to work closely with professionals trained in the law, who can guide them through investigative steps without threatening democratic institutions by mistake.

\section{The Role of the Prosecutor}

The role of the prosecutor is a crucial role, for it is the prosecutor who can most vigorously assert one of the central demands of the rule of law, that the powerful, including elected leaders, are subject to the law and cannot legally or safely serve their private interests. Making this point effectively with the public is at the heart of the task of dealing with corruption.

The most serious problem in every country is that prosecutors are suspected of being heavily involved with the potential targets of their investigations. They are, therefore, suspected of either favoring friends among the powerful or unfairly targeting opponents of the powerful. Moreover, to the extent the prosecutor succeeds in embodying public demands to pursue and punish the corrupt, the prosecutor becomes a prominent political figure, adding to the suspicions of his motivations. We have seen examples of this in the United States, ${ }^{33}$ Italy, ${ }^{34}$ Spain, ${ }^{35} \mathrm{Ar}$ -

33. Neil A. Lewis, Special Prosecutors' Inquiries Have Led to Doubts About Their Usefulness, N.Y. Times, Dec. $1,1996, \S 1$, at 38.

34. Charles Trueheart, Ciao Time for Italy's Harassed Graft-Buster, WASH. Post, Nov. 26, 1996 at A10. Antonio di Pietro became the most prominent magistrate investigating 
gentina, ${ }^{36}$ and Colombia. ${ }^{37}$

The major problem is, thus, to insure in a way that is credible to the public that a prosecutor is willing to bring cases against the powerful and to resist pressure to bring unwarranted cases against the opponents of the powerful. This assurance may not be achieved by a public pressure so intense that the prosecutor will be responding or catering to it and not to the merits of the case.

For these reasons, there are a variety of devices in the United States for providing "outside" prosecutors in some cases of political corruption. Federal prosecutors attached to the national Government handle most cases of state and local corruption. In addition, an independent counsel, appointed by judges, handles federal cases involving the highest level officials in the Federal Government. Even such special prosecutors require reliable investigators, but we have found that the Federal Bureau of Investigation can handle that responsibility with independence and skill.

There are, of course, problems with special counsel. They are likely to be less familiar with the operations of a government. They may have a strong desire to establish their own reputations at the expense of political figures. They may be reluctant to dismiss technical or ambiguous conduct that is generally ignored and should not really be treated as criminal. They do guarantee, however, credibility in this politically sensitive area.

\section{Adequate Court Systems}

Finally, criminal prosecutions are essential to guarantee the integrity of a system, particularly with regard to high-level officials, and they depend upon court systems that are adequate and sufficiently independent to try major figures. I have worked in developing countries where neither capacity nor independence could be assumed. The result is that any such trial would some-

the "clean hands" scandal, which revealed widespread corruption in Italian politics and business. Id. Di Pietro himself has been charged with corruption several times. Id.

35. Unpopular Parties, ECONOMIST, Dec. 14, 1996, at S13.

36. Sebastian Rotella, Angentine President Lashes Out At Corruption Charges; Latin America: Menem Calls Rivals "Irresponsible." They Have Linked Administration to Drugs, Murder and Mafia, L.A. Times, Oct. 17, 1996, at Al1.

37. Sam Dillon, Colombia's Chief Is Charged But a Tangled Inquiny Looms, N.Y. TIMES, Feb. 16, 1996, at A2. 
how get delayed and obstructed along the way and would be unlikely to lead to a guilty verdict even when it was clearly warranted by the evidence. Charges against the wealthy and the powerful are always difficult to handle efficiently, promptly, and at reasonable cost. They must be pursued, however, or the anticorruption system will lack credibility. If the promotion of judges in a career system or future political appointment in a system that selects its judges in that way obviously depends upon the favor of those who are being tried, the results will also lack credibility.

All this is true of more than courts. Each of the agencies that I have described must somehow be given a substantial amount of independence from the highest political leadership. So must the committees of the legislature that can investigate corruption. There are a variety of devices for this even within an administration. Under President Jimmy Carter, Attorney General Griffin Bell published rules stating that my decisions as the Chief Prosecutor would not be overruled by my superiors except in public and with an explanation of reasons. ${ }^{38}$ A legislature may create similar protections for prosecutors through provisions like our independent counsel laws. Most important, of course, is tradition. High political officials may make it public and obvious that they will respect a tradition of independence of law enforcement officers, particularly in cases alleging crimes by high officials. This in turn, however, often depends upon popular demands.

\section{Popular Demands for Political Leaders to Take the Steps Described Above to End Corruption}

The simple fact of the matter is that high level officials have little incentive to take the issue of corruption seriously, aside from public demands enforced through election machinery. This is obviously true if officials are themselves vulnerable to exposure for improper actions. I helped set up the Independent Prosecutor's Office that investigated President Richard Nixon for Watergate. ${ }^{39}$ The President did not willingly take the step of

38. See Daniel J. Meador, The President, The Atrorney General, and the DePARTMENT OF JUSTICE 58-60 (1980) (discussing procedures in the Attorney General's office).

39. Babcock, supra note 1, at A9. 
appointing a special prosecutor, Archibald Cox. ${ }^{40} \mathrm{He}$ did not willingly take action against his own chief aides, John Ehrlichman, ${ }^{41}$ Bob Haldeman, ${ }^{42}$ Charles Colson, ${ }^{43}$ and John Dean. ${ }^{44}$ He did not willingly turn over tapes that would expose his own wrong-doing. ${ }^{45}$ He did not willingly appoint a new special prosecutor after firing Archibald Cox. ${ }^{46} \mathrm{He}$ took each of these steps because the immense power of the public demands that he take them and for no other reason.

Even when elected officials are less directly involved, however, they are unlikely to find advantage in pursuing corruption in their own houses. Elected officials have other more important issues to worry about. They know that something close to corruption often funds their campaigns and their parties. Exposure of self-dealing within their governments creates more bad publicity than good. Moreover, those revealed to be involved in corruption are likely to point their fingers at others. Finally, the targets of corruption investigations are likely to be friends or supporters of high political leaders.

Despite all this, there is a great interest throughout the law enforcement community in the United States in bringing corruption cases, and there is no likelihood of a high political figure preventing these institutions from carrying out their responsibilities. What makes the response to corruption vigorous in the United States is the political potency of the issue and, particularly, of accusations of "cover-up." It is the reciprocal support of formal and informal systems, of government and press, of investigation and scandal. This has been true in the case of Watergate, ${ }^{47}$ Iran-Contra, ${ }^{48}$ Whitewater, ${ }^{49}$ and every other major public

40. Fred Emery, Watergate, The Corruption of American Politics and the Fall of Richard Nixon 355-57 (1994).

41. Id, at 245.

42. $I d$, at 296.

43. See id. at 242, 426-28 (describing Colson's departure from White House and later indictment).

44. See id. at 292-302, 318 (describing circumstances of Dean's departure).

45. Id. at 370, 405-06.

46. Id, at 407.

47. EMERY, supra note 40 , at xi-xiii. Watergate refers to the Washington, D.C. apartment complex where the Democratic National Committee headquarters was burglarized on June 17, 1972. Id. The ensuing payoff to the Watergate burglars and the White House coverup led to the resignation of President Richard Nixon. Id.

48. LaWrence E. Walsh, Final Report of the Independent Counsel for Iran/ Contra Matters reprinted in Lawrence E. Waish, Iran-Contra: The Final Report xv 
investigation.

For many countries, the problem is to create or release public anger at corruption and at the failure to deal with it. The public can become passive if it believes that corruption is inherent in the very nature of government, that the state goes its own way and is not responsive to public demands, that everyone in private or public life is out for themselves anyway, and that coverup is the normal practice of governments. These turn out to be self-fulfilling beliefs because they kill the political demand for honesty by making it seem naive, undermining public spiritedness and hope. Yet, without a powerful, public demand for strong action against corruption, political leaders will not act against it, and a failure to act reinforces public skepticism. So the cycle goes on and on.

A government that wants to dispel these self-fulfilling doubts and encourage the public demands that are the final guarantee of significant action against corruption must take dramatic actions that establish hope. Internal reforms and reorganizations are unlikely to have this effect. The public is too likely to believe that they are just for show. What is often necessary is to bring charges against the highest level officials who are corrupt and to dramatically withdraw political control of how the charges are then handled, leaving that to judicial and prosecutorial professionals.

There is, at least potentially, a great public interest in corruption and cover-up. This is manifest all over Europe, the United States, and Japan with considerable regularity. It is also true of Latin America. That interest may be swamped by intense concerns about a war or depression, but it is likely to be very prominent at most times. Only a widespread and profound cynicism can eliminate that interest. It is the core responsibility of political leaders to prevent that cynicism, that distancing from the state and from any sense of public responsibility, from occurring. That is the final requirement for fighting corruption.

(1994). The Iran-Contra affair involved the secret efforts of the Reagan Administration to obtain the release of hostage U.S. citizens in the Middle East through weapons sales to Iran despite an existing arms embargo. Id. The Administration also secretly supported Nicaraguan rebels, the Contras, despite a Congressional ban on such aid. Id.

49. Monkey Business?, Economist, Jan. 18, 1997, at 21. Whitewater was a failed Arkansas land deal. Id. An independent counsel is investigating President Clinton's possible involvement with fiscal improprieties related to Whitewater. Id. 